Teosofia: Indonesian Journal of Islamic Mysticism, Vol. 9, No. 1, 2020, pp. 91-112

e-ISSN: 2540-8186; p-ISSN: 2302-8017

DOI: $10.21580 /$ tos.v9i1.5328

\title{
TABATABA'I INTERPRETATION ON PROPHETIC MISSION IN TAFSIR AL-MIZAN FOR THE CONSTRUCTION OF NUSANTARA SPIRITUAL CIVILIZATION
}

\author{
Achmad \\ Sekolah Tinggi Filsafat Islam Sadra \\ achmadzegaf1998@gmail.com \\ Fadhlu Rahman \\ Sekolah Tinggi Filsafat Islam Sadra \\ gt630111@gmail.com \\ Pia Nuraripah \\ Sekolah Tinggi Agama Islam Al-Azhary \\ pianuraripah.123@gmail.com
}

\begin{abstract}
:
Modernism as the product of Renaissance has succeeded in couping the reality of God. The view of several western intellectuals have caused to the obscurity of human concepts which then affects to the meaning of the progress of human civilization, and further, presents serious problems almost in all social life. In the context of the archipelago (Nusantara), some Islamists groups try to establish a civilization based on materialistic point of view and with textual interpretation of the Qur'an. In fact, Islam in the archipelago genealogically has characteristics which are very spiritual so it is not appropriate to develop an advanced civilization in the archipelago based on materialist achievements as promoted by western modernism. The prophetic mission interpreted by Tabataba'i in al-Mizān fi Tafsìr al-Qur'an verses 1-2 and 5 gives the concept of spiritual civilization based on the Qur'an which is in line with the character of the archipelago. Thus, this study seeks to answer these research questions: first, how is the prophetic mission interpreted by Tabațaba'i in his Tafsìr al-Mizān constructing spiritual civilization? Second, how is the construction of spiritual civilization in harmony and able to actualize the treasury of the archipelago? The method used in this study is a descriptive analysis with the approach of Tabataba'i's interpretation (Tafsir) on the prophetic mission. The study finds that Tabataba'i interpretation on the Surah al-Jumu'ah verses 1-2 and 5 gives the spiritual construction of civilization that is in line with the character of the archipelago.
\end{abstract}

Keywords: Spiritual Civilization, Prophetic Mission, al-Mizan, Tabațaba’i Interpretation 


\section{A. Introduction}

ccording to Thomas Khun as quoted by Fritjof Capra that scientific truth is 1 nothing but based on a collection of concepts, values, and perceptions of 1 certain societies from which a perspective or vision of world reality is formed. ${ }^{1}$ According to Khun, the objectivity of truth depends on these collections of values. This means that the majority of the group is the determinant of the vision of the truth. The western vision constructed by the Renaissance and Enlightenment has caused a very significant impact on civilization. ${ }^{2}$ This vision was born from rational philosophers and scientists such as Descartes, Hobbes, and Bacon who have spearheaded for the birth of modernism. They called this era as Turning to nature directly, turning to mind directly, and turning to experience directly. ${ }^{3}$ Hossein Nasr called it as "removing God from the center of the reality and putting man in His place". 4

God's authority was then replaced by humans. They consider it a concept that lies in human beings, not a reality that exists independently. This can be justified by Mario Bunge's theory about identity. He shows that every thought has a nerve function in the brain, meaning that if the brain does not exist then the mind does not exist. ${ }^{5}$ Likewise, God as a conceptual conception of human beings can disappear along with the loss or damage of the human brain. The sacredness of God by most western thinkers gave birth to the concepts of advanced materialistic civilization. Maxwell J. Mehlman and Jhon Harris, for example, define human quality improvement as an increase in physical performance, appearance, and capability. ${ }^{6}$ Thus, humans who are icons of civilization are said to be advance when developing or increasing their physical aspects.

But the paradigm of modernism initiated by the West for almost centuries has given rise to crises in various aspects, not only science but also socio-cultural. Fritjof Capra sees the uncertainty of objectivity of modern physics as the cause of various crises and make modern physics a paradigm for viewing the universe. "According to what we are seeing is a shift of paradigm not only in science but also in the larger

1 Fritjof Capra, The Web of Life (New York: An Anchor Book, 1996), 6.

2 Toby E Huff, The Rise of Early Modern Science (New York: Cambridge University Press, 2003), 326-327.

3 Donald M Borchert, Encyclopedia of Philosophy, ed. Donald M Borchert (New York: Thompson Gale Corporation, 2006), 316.

4 Seyyed Hossein Nasr, Knowledge and the Sacred (New York: State University of New York Press, 1989), 209.

5 Mario M Bunge, Matter and Mind(Montreal: Springer, 2010), 160.

6 Ronald Cole-Turner, Transhumanism and Transcendence (Washington DC: George Town University Press, 2011), 1. 
social arena"7 Besides, he said that this gave existential problems to humanity. "Their problems were not merely intellectual but amounted to an intense emotional and, one could say, even existential crisis. It took them a long time to overcome this crisis, but in the end, they were rewarded with deep insights into the nature of matter and its relation to the human mind". 8

In the context of the archipelago (Nusantara), one of the principles of western modernism is in line with several variants of Islamism in Indonesia that try to develop advanced civilizations based on materialistic viewpoint but claim to building spiritual civilizations. According to Bassam Tibi, a founder of Islamic studies as a social study of Islam and politics says:

"Stated in a nutshell: the agenda of a pax Islamica pursued by the Muslim Brotherhood reflects a totalitarian ideology; the Islamist variety of religious fundamentalism in the pursuit of a remaking of the world to conform to hakimiyyat Allah. This new totalitarianism does not restrict its goals to the abode of Islam but is designed for the world at large. The "moderate" (institutional Islamist) Muslim Brotherhood is, like the jihadist al-Qaeda, a movement based on internationalism in the Marxist sense." ${ }^{\prime}$

This phenomenon is in line with the vision of materialism. This is because materialism definitively prioritizes material things compared to others ontologically. Related to this, Keith Campbell in An Encyclopedia of Philosophy said that "Materialism is the name given to a family of doctrines concerning the nature of the world that gives to matter a primary position and accord to mind (or spirit) a secondary, dependent reality or even none at all. ${ }^{\prime \prime} 0$

Thus from the ontological aspect, the Islamic political movements measure the success of leadership with material things. This is because the expansion of territory is a measure of success in leadership and civilization establishment. One of the materialistic principles is used by them in understanding the Qur'an as the basis for justification or legitimacy of all Islamism movements in building a civilization. They refer al-Qur'an Surah al-Baqarah [30]:

'Remember when your Lord said to the angels, "I am going to make the Caliph on the earth, they say," Why do you want to make the Caliph on the earth the one who has caused harm and shed blood, when we have always glorified and praised You and Purified? God answers, indeed I know that which ye know not (QS, Al-Baqarah: 30)."

\footnotetext{
Capra, The Web of Life..., 5

8 Capra..., 5

9 Bassam Tibi, Islamism and Islam (London: Yale University Press, 2012), 219.

10 Borchert, Encyclopedia of Philosophy...., 5.
} 
Rahmat S Labib, one of the HTI figures quoted by Lufaefi, interpreted the word caliph as an obligation to appoint a caliph, and then applied all the laws and rules in a governmental order with Islamic Sharia according to the teachings of the prophet. ${ }^{11}$ So, it appears that the model and pattern of textual interpretation use a materialistic perspective as a measure of success.

Such characteristics are not compatible with those of the archipelago as they are genealogically and historically posses strong aspects of spirituality. This is evidenced in the beliefs of the local community before the coming of foreign outside religions such as Islam, Hinduism, Buddhism, and others. Forshee stated that Indonesia truly has a belief in animism, where all nat ure is believed to have spiritual power:

"To begin to understand various Indonesian ways of thinking and religious convictions, one needs to first consider animism, which long preceded imported world religions in the archipelago and currently weaves through most of them. In Indonesia beliefs in spirits of the earth, air, and waters combine with concerns about the ongoing supernatural powers of ancestors; visible and invisible realms both hold sway in everyday life."12

The spiritual character in the archipelago is manifested in the life of Sufism traditions, which portrays not only the esoteric religious aspects but also politics as said by Nur and Abdurrahman:

"In the history of the archipelago the tarekat not only recorded as a group of dhikr assemblies that only concentrate on the relationship with God alone and ignorant of the surrounding social circumstances. Unlike some people, who said that the tarekat is to be one of the causes of the decline of Islam, the tarekat in the archipelago has also quietly contributed greatly to the social order in society. As far as history is observed, there have been many struggles or oppositions committed by the tarekat against the occupiers of that time, such as the resistance of the Qadiriyah wa Naqsyabandiyah congregation in Banten 1888 and others. In fact, some tarekat is a group of people who feared the Dutch colonial government because of their resistance movements. In addition to fighting in the forms of political resistance, tarekat also recorded to have been an institution that protects the community, such as tarekat Syattariyah in West Sumatra. Thus, it can be said that in addition to having a religious function, certain tarekat also have political power. Charismatic Syaykhs will be able to play an important role in recruiting masses and in politics as well'. ${ }^{13}$

11 Lufaefi, "Rekonstruksi Jargon Formalisasi Syariat: Upaya Menjaga Persatuan dalam Bingkai Keberagaman," Al-A'raf: Jurnal Pemikiran Islam Dan Filsafat 14, no. 1 (2017), 73.

12 Jill Forshee, Culture and Customs of Indonesia (London: Greenwood Press, 2006), 30.

13 Syaifan Nur and Dudung Abdurahman, "Sufism of Archipelago: History, Thought, and Movement," ESENSIA: Jurnal Ilmu-IImu Ushuluddin 18, no. 2 (2018), 123. 
Thus, the main characteristics of traditions and national identities require the concept of civilization development that is in line with the Quran considering many social problems are caused by textual interpretation of the Quran by the Islamism in establishing civilization, especially in the archipelago.

Tabațaba'i's understanding about prophetic mission in his tafsir al-Mizan provides a concept of civilization that is based on al-Qur'an and in line with the character of the archipelago. ${ }^{14}$ Although the archipelago is Sunni majority, they are similar to Syi'i in the spiritual context as Syihabuddin Suhrawardi Said. ${ }^{15}$ Thus, this study seeks to answer these research questions: first, how is the prophetic mission interpreted by Tabațaba'i in his book of Tafsir al-Mizan constructing spiritual civilization? Second, how is the construction of spiritual civilization in harmony and able to actualize the treasury of the archipelago?.

At least there are six relevant studies related to this issue i.e. "Memaknai Kembali Spiritualitas Islam dalam Peradaban Kontemporer" by Baedhowi; "Civilization in Islamic Perspective" by Jamil Farooqui; "Spiritualisasi Keilmuan: Mengkontruksi Peradaban Intelektual Muslim Abad ke 21" by Moh. Miftahusyaian; "Al-Qur'an Sumber Peradaban" by Abd Wahid; "Mission of Islamic Education Propetik: Forming Character Towards Social Transformation Building Civilization" by Askar.

The first study aims to reinterpret the meaning of Islamic spirituality in the contemporary era by tracing its historical roots through the development of Sufis. ${ }^{16}$ The author concluded that reinterpretation of one of the leading concepts of Islamic spirituality (Wahdat al-Wujūd) made ethical, moral, and spiritual contributions to Islamic spirituality in the contemporary era. The second study explores the concept of Islamic civilization by contextualizing it with the definition of civilization. ${ }^{17}$ The author finds that the nature of the development of social organizations that are part of the elements of civilization leads to the nature of its creation outlined by God. ${ }^{18}$ The third study focuses on reconstructing civilization by reforming the principles of civilization during the reign of the prophet in Madinah and contextualizing them in civilization today. ${ }^{19}$ In the fourth study, the author tried to offer the concept of

14 Muhammad Husein Țabațaba'i, Al-Mizan Fi Tafsir Al-Qur'an, vol. 19 (Qum: Mansturat Jamiah Mudarrisin fi Hauzah Ilmiyah, 1997), 265.

15 Syihabuddin Umar Suhrawardi, Al-Awārif Al-Ma'ārif(Kairo: Dar Al-Ma’arif, 1970), 98.

16 Baedhowi, "Memaknai Kembali Spiritualitas Islam Dalam Peradaban Kontemporer," Millah 3, no. 20 (2004), 221.

17 Jamil Farooqui, "Civilization in An Islamic Perspective," Journal of Islam in Asia (E-ISSN: 22898077) 8 (2012), 409-26.

18 Farooqui, “Civilization in An Islamic...., 409.

19 Moh Miftahusyaian, "Spiritualisasi Keilmuan: Mengkonstruksi Peradaban Intelektual Muslim Abad Ke-21," El-HARAKAH, vol. 12, no. 1 (2010), 1. 
Islamic civilization based on al-Qur'an. ${ }^{20}$ The author concluded that the civilization contraception especially Islam based on al-Qur'an was known through the initial process of the existence of Islam as a religion that contains perfect teachings for the development of civilization. ${ }^{21}$ The fifth study explored the prophetic mission of Islamic education to build a transformation of an advanced civilization. ${ }^{22}$ The author found that the pattern to realize social transformation in building a civilization based on the mission of Islamic education is to emphasize the cultivation of faith and worship and the formation of good character. ${ }^{23}$ Yet, the above five studies have not emphasized the Qur'an as the basis for the construction of spiritual civilizations that are in line with the characteristics of the archipelago. Therefore, this study is unique as it uses the Qur'anic approach and the concept of spiritual civilization as raw material for constructing the civilization that God intended through the prophetic mission.

The method used in this study is a descriptive analysis with the approach of Ṭabataba'i's interpretation (Tafsīr) on the prophetic mission. The data are derived from his Tafsir al-Mīzān fì Tafsīr al-Qur'an which then the authors contextualize it with the concept of Coomaraswamy's spiritual civilization, as a foothold of the meaning of civilization as well as the framework of the concept of civilization through descriptive analysis methods. Thus, the development of civilization gets a spiritual perspective as well as in line with the character of the archipelago and hopefully can maximize the potential of the treasury of the archipelago.

\section{B. The Importance of Spiritual Values}

The discussion of the height of the value of spirituality is a prerequisite as well as a conceptual device to be able to explain the construction of spiritual civilizations in the interpretation of prophetic missions. These values will be used as the basis of the construction of spiritual civilization. In addition, also to find out the extent of the importance of these values in a civilization that will be built. Spirituality comes from Latin meaning spirit, soul, form which has no body, breath, or life. The spiritual means mental, spiritual, and moral. While spirituality is a process to reach the highest peak of consciousness. From these three syllables, we can eliminate the meaning of spirituality as a process to achieve self-actualization

20 Abd Wahid, “Al-Qur'an Sumber Peradaban”, Ushuluddin 18, no. 2 (2012), 111,122.

21 Wahid, “Al-Qur' an Sumber Peradaban...., 122.

22 Askar Ahmad, "Misi Propetik Pendidikan Islam: Membentuk Karakter Menuju Transformasi Sosial Membangun Peradaban," HUNAFA: Jurnal Studia Islamika 8, no. 1 (2011), 175.

23 Ahmad, "Misi Propetik Pendidikan Islam..., 186. 
based on or driven by spiritual power. ${ }^{24}$ This means that the thing that is at the core of self-actualization power comes from the spiritual substance. The substance of this spirit is emphasized by Nasr in In Search of the Sacred: "spirituality is to be in contact with the world of the spirit and that transcends all particularities of the human state and of the material world" ${ }^{25}$

This spiritual thing becomes a separate dimension in humans. The spirit is a core reality of humans. From him, all the energy of human potential comes from. In his dissertation, Irham Iqbal put Ruh's position as a genus of the soul. Its reality is directly related to Divine aspects. Without it the soul cannot function, so the soul cannot move material potentials such as sight, hearing, smell, touch, and taste. ${ }^{26}$

The existence of the spirit is very closely related to the soul. The soul which is the essence of man is positioned between two ontological realities, namely, spiritual in the form of spirit, and the material body. ${ }^{27}$ The human soul moves in a certain direction depending on the use of its potential. Many Muslim philosophers mention the concept of the movement of the potentials of the soul, among others, are al-Ghazali in Kimmiya al-Sa'ādah and Ibn Miskawaih in Tahzīb al-Akhlāq, quoted by Nur Hanim. Both of them explained in detail the potentials of the soul which consisted of three core faculties including al-quwwah al-nātiqah, al-quwwah alghadabiyyah, and al-quwwah al-shahwiyyah. Whereas al-Ghazali termed it with the terms nafs al-insāniyyah, nafs al-hayawāniyyah and nafs al-hayawaniyyah. Each of these three potentials has two positions including, the advantages and disadvantages of al-tafrit and al-ifrat. Al-Ghazali and ibn Miskawaih both used the middle ground doctrine as the main position of al-wasat. So that the soul that successfully uses its potential is a soul who gets the middle position of each potential including alhikmah, al-shajā'ah, and al-iffah. ${ }^{28}$ The condition of these three souls can bring man to the center of his energy in the form of spirit and get the highest awareness of the universe.

The highest consciousness becomes the peak of the true human condition. With it, one can see the reality of the world as it is. This ability is based on human nature which is part of God. This is justified by the process of creating the cosmos

24 Muhammad Iqbal Irham, Menghidupkan Spiritualitas Islam: Kajian Terhadap Konsep Hudur Ibn AlArabi (Jakarta: Semesta, 2016), 37

25 Nasr, Knowledge and the Sacred, 168.

26 Irham, Menghidupkan Spiritualitas Islam...., 30-32.

27 Afandi Nur Aziz, "Spiritual Path of Grave Digger," Teosofia: Indonesian Journal of Islamic Mysticism 7, no. 1 (2018). 53.

28 Nur Hamim, "Pendidikan Akhlak: Komparasi Konsep Pendidikan Ibnu Miskawaih Dan Al-Ghazali," Ulumuna 18, no. 1 (2017): 21-40, 151. 
which Muslim philosophers call emanation ${ }^{29}$ or Suhrawardi's theory which specifically states that humans are part of God's light which is graded from nonmaterial peak light to the darkness of the material peak, ${ }^{30}$ as well as Mulla Sadra who said that humans are sourced from the reality of the one essential. It becomes a source of clarifying other realities. ${ }^{31}$ These theories indicate the status of human beings who have the characteristics of God because they are created from the elements of God (attributes). Thus, humans are enabled by God to get the highest awareness.

Regarding the process of gaining the highest level of awareness, Nasr in his book Knowledge and The Sacred states:

"The answer of tradition is that the twin source of this knowledge is revelation and intellection or intellectual intuition which involves the illumination of the heart and the mind of man and the presence in him of knowledge of an immediate and direct nature which is tasted and experienced, the sapience which the Islamic tradition refers to as "presential knowledge." 32

That awareness of absolute reality can be obtained through two basic epistemologies namely, revelation and intellectual intuition. The process of acquiring that knowledge by presenting it in oneself. This knowledge is often named by some Muslim philosophers as al-Ilm al-Huduri which means present itself. What distinguishes between huduri and husuli is the intermediary it uses. Huduri did not use a mental intermediary to gain knowledge, whereas husuli used a mental intermediary. ${ }^{33}$ Ibn Turkah, quoted by Khorsidi, referred to this as an angelic incoming thought, which specifically humans got after going through a process of self-purification. ${ }^{34}$

Purification of self in question is not arbitrary without the process of thinking theoretical sense. Ibn Turkah said that the good we do must be based on a decision of theoretical reason. That is, however, the role of theoretical reasoning must be balanced with the process of self-purification prepared to receive God's knowledge. ${ }^{35}$ Further in practice, explained by Fatemeh Tayefeh's dissertation about Abdurrazaq al-Kashani with his book Tuhfat al-Ikhwān fĩ Khasaị̣ al-Fityān states that knowledge of absolute

29 Seyyed Hossein Nasr, History of Islamic Philosophy (London: Routledge, 1996), 446.

30 Peter S Goff and Leaman Oliver, Islamic Philosophy $A-Z$ (Edinburg: Edinburg University Press, 2007), 201.

31 Sadr al-Muta'alihin Shirazi, Mazahir Al-Ilahiyyah Fi Asrar Al-Ulum Al-Kamaliyyah (Tehran: Sadra Foundation of Islamic Philosophy, 1999), 15.

32 Nasr, Knowledge and the Sacred, 119.

33 Muhsin Labib, Pemikiran Filsafat Ayatullah M.T Misbah Yazdi (Jakarta: Sadra Press, 2011), 158.

34 Faridi Khorsidi and Mona, "Comparing Mulla Sadra and Ibn Turka Viewpoints Regarding Angelic Inspiration,” J. Basic. Appl. Sci. Res 3, no. 2 (2013), 582.

35 Khorsidi and Mona "Comparing Mulla Sadra and Ibn Turka...., 582. 
reality can be obtained through praiseworthy qualities. These qualities he quoted from Sayyidina Ali include loyalty, security, humility, generosity, repentance, advice, protection, and honesty. ${ }^{36}$ With these praiseworthy attitudes, people will get a true awareness of their existence and gain essential knowledge about the reality of God. This awareness as al-Ghazali and Ibn Miskawaih alluded to as a balanced use of the potentials of the human soul, or Coomaraswamy calls true servitude to God in the human heart. All of this is nothing but based on the spirit of the human spirit that always leads to God.

\section{Coomaraswamy's Framework and His Concept of Civilization}

One who can define civilization in this context is Ananda Coomaraswamy, a perennialist philosopher. In his article entitled What is Civilization? he tried to explain the intrinsic meaning of the terms "civilization", "politics" and "purusa". These three things become the basic principles of the meaning of civilization which will be discussed. This he addressed as an answer to the question of Abert Schwitzer, who saw the obscurity of the meaning of modern western civilization. Coomaraswamy began by defining civilizations from Greek and Sanskrit. In Greek it is rooted in the word keisthai, Sanskrit si, meaning to lean or to be housed. So this language is interpreted as a place where citizens live, or he termed "in which the citizen makes his bed". ${ }^{37}$

Then who lives? or who is the citizen? He states that the purusa is the one who lives in it. Purusa is a union of two words of political meaning rooted in pla and pimplemic. These two words mean "to serve", and "fort". ${ }^{38}$ Meaning that in language there are two elements that live in the place, among others, servants and guards as a fortress. So that if we contextualize these two things in one place, it means that there are citizens and kings.

He interpreted citizens as humans whose king is God. Coomaraswamy quotes Plato's conversation with Philo in The Republic. Philo said that God is the king of that place: "As for lordship (Kyrios), God is the only citizen" while the man he attributed to Adam is his citizen: "Adam is the only citizen of the world". ${ }^{39}$ Both of these are elements of the place in question, and both must be mutually sustainable in order to create harmony in a government.

36 Fatemeh Tayefeh Aghakhan Hashtroodi, Concept of Chivalry (Futuwwah) According to Abd alRazzaq Kashani: Analysis on His Tuhfah al-Ikhwan fi Khasais al-Fityan (Kuala Lumpur, Malaysia, 2015), 144.

37 Ananda K Coomaraswamy, What Is Civilization?(United Kingdom: Lindisfarne Press, 1989), 1.

38 Ananda K Coomaraswamy, The Essential Ananda K(Bloomington: World Wisdom, 2004), 202.

39 Coomaraswamy, The Essential Ananda K, 202. 
Then where is the city located? Coomaraswamy said that it was covered by human beings. It is in the human heart that God's city as absolute reality is housed. From it, all the potential human energy comes from: "Thus at the heart of the City of God inhabits the omniscient, immortal Self," this self's immortal Self and Duke, "as the Lord of all, the protector of all, the Ruler of all beings and the Inward Controller of all the powers of the soul." 40 But, it cannot be understood that God's place means that the essence or existence is in man, but God's city can be found in man as Plato said: "as of the city is within you and literally at the of the city". ${ }^{41}$

The City of God acts as the source of all energy for human potential. Body and soul without it are weak and helpless. Its presence in humans is like a king who always maintains that human existence. Coomaraswamy analogized it like someone who always made offerings to the Altar, where he always hoped to be able to stay by begging for his protection and welfare. This relationship is able to give hope to humans to always exist (exist) and get a comfortable place as a citizen. Thus, good citizens are the most obedient to their king. ${ }^{42}$ So God is made the center for all human activities, because God, a servant moves to do what he was told. Thus the relationship between God and humans is a very close matter, and it becomes a necessity for humans to obey God as a whole so that life in the city of selfhood can go well.

In a government, of course, there must be a law that runs. This Coomaraswamy referred to as a form of naturalness. ${ }^{43}$ Naturalness in question refers to all the potentials of the human soul, which all of these will deliver a man to his heart as the source of his energy. Justice becomes the thing that is upheld by a good government, as well as the potentials of the soul. If the full potential of the actual soul is in accordance with the natural potential of its potential as a form of justice, there will be harmony or justice. This harmony which then leads a person to the center of all potential energy regulators, as he says: " The right and natural life of the powers of the soul is then, precisely, their function of bringing tribute to their fountain-head, the controlling Mind and very Self."44

This situation certainly requires a good self-introduction, as well as knowing the characteristics of these potentials so that he can use them in accordance with his natural experience. Al-Kashani an Islamic philosopher explained by K. Vasiltov said that self-recognition can reach an essential awareness of absolute reality (God): "he

40 Coomaraswamy, The Essential Ananda K, 202.

41 Coomaraswamy, The Essential Ananda K, 202.

42 Coomaraswamy, What Is Civilization?, 5.

43 Coomaraswamy, The Essential Ananda K, 201.

44 Coomaraswamy, The Essential Ananda K, 205. 
aims at recognizing God sign in the" big "world through the recognizing of the human world". ${ }^{45}$

To be able to achieve this, at least there are some characteristics that are required to create a fair self-government order. According to Coomaraswamy, it includes wisdom, sobriety, and courage. All potential given by God such as hearing and vision must be used proportionally, because this is a condition of achieving these characteristics, so that humans are said to be humans when all their potential can function properly. Thus, it leads to absolute reality. On the other hand, if humans cannot use their potential proportionally, then they will be far from absolute reality. ${ }^{46}$

From the concepts it builds, it can be concluded that the civilization in question is a place within a person. Civilization in the form of a city is nothing but occupied by God as its king and humans as its citizens. Justice that is carried out in a person is a prerequisite for the achievement of the perfection of government within oneself. This is obtained by all the potential used proportionally so that the principle needed to create this condition is to meet the material and non-material needs that exist in a person. The good civilization in this context is how far a person is able to meet his needs. This is Coomaraswamy quotation from the book Republic: "This purpose is to satisfy a human need". ${ }^{47}$

\section{Prophetic Mission in Tafsīr al-Mizan Surah al-Jumu'ah Verses 1-2 and 5}

Before knowing the discussion of the prophetic mission in the interpretation of al-Mizan, it is necessary first to understand the first verse in the Surah. This verse begins with information that everything on earth and heaven glorifies God.

"Always glorify Allah what is in the heavens and what is in the earth, the King, the Holy, the Mighty, the Wise (QS, al-Jumu'ah: 1)"

From the expression of the verse, we can draw a question of what a beehive is. Tabațaba'i answers in his interpretation of the verse: The purse is an attempt to purify something of all defects and deficiencies. ${ }^{48}$

As for the word bead in the first verse is used in the form of the verb Mudari' to indicate the continuity of the bead to God. Not only that, God also treats himself in the first verse with the holy nature of the divine meaning. The word al-holy in

${ }^{45}$ K. Vasiltov, "Afdal Al-Din Kashani and His Treaties: The Book of Everlasting," International Journal for Oriental Manuscript Study 10, no. 4 (2004), 10.

46 Coomaraswamy, The Essential Ananda K, 205.

47 Coomaraswamy, What Is Civilization?, 6.

48 Ṭabațaba'i, Al-Mizan Fi Tafsir Al-Qur'an, 263.

$$
\text { التسبيح تنزيه الشيء و نسبة الى الطهارة و نزهة من العيوب و النقائص }
$$


Arabic has a meaning to emphasize something, and in this verse God wants to emphasize his holiness so that all good things on earth or in heaven are always glorified (in addition to always being pure in him), besides, there is also the nature of al-mālik, al-aziz and al-hakìm in the last paragraph of the first paragraph of this Friday Surah. ${ }^{49}$

Besides, because he is sacred, why do all beings always praise him? This is the answer to the first paragraph of the Al-Jumu'ah Surah which is the second verse that reads:

"It was He who sent among the people a Messenger among them, who recited His verses to them, purified them and taught them the Book and Wisdom. And indeed, they were actually in a real error (QS, Al-Jumu'ah: 2)."

The relationship between the first and second verses, especially in connection with the question of why God should be purified, is because he sent his messengers as stated: Tabațaba'i: The apostles were sent to perfect, send forth happiness, and give men guidance after they were in error. ${ }^{50}$

Thus, human perfection is closely linked to the decision of God's messengers, so that if God does not send his messengers, then man cannot easily attain perfection, happiness, or guidance. Thus, the human being is very much in need of perfection because within himself there are various deficiencies, and the perfection of those deficiencies is God who is the owner of absolute perfection. Of course, if he does not have absolute perfection, then he needs another perfection of nature, and this is a defect. Therefore, it is appropriate for us to inculcate and sanctify our holiness to God. This is also stated by Ṭabațaba'i:

Therefore, all good creatures who are on the face of the earth and sky glorify (purify Him) because basically they have weaknesses and needs which God is the perfect and complete the weaknesses and needs. That is why $\mathrm{He}$ is purified from all deficiencies and disgraces, because basically $\mathrm{He}$ is perfect who perfects the various shortcomings of his creatures. ${ }^{51}$

49 Țabațaba'i, Al-Mizan Fi Tafsir..., 263.

50 Tabațaba'i, Al-Mizan Fi Tafsir..., 263.

هو الذي بعث الخ من بعثة الرسول لتكميلهم واسعادهم وهدايتهم من الناس بعد اذ كانوا فى ضلال مبين

51 Ṭabaṭaba'i, Al-Mizan Fi Tafsir..., 236.

وذلك أنها تعالى يسبحه وينزهـ الموجودات السماوية والأرضية بما عندهم من النقص الذي هو متمماه والحاجة التي هو قاضيها فما من نقيصة أو حاجة إلا وهو المرجو في تمامها وقضائها فهو المسبح المنزه عن كل نقص وحاجة 
So, what are the consequences if He is perfect and pure from lack? According to Tabațaba'i, as stated in his book: He should have authority over the creation (alkauni) and the legal (al-tashri). ${ }^{52}$

As explained above, since he is perfect, he has mastered the system of creation among his creatures as he wishes. For example, in the aspect of creation, it is God who has perfected us, at first we are in a state of potential existence which then becomes actual. We exist because it is held by it, we cannot manifest ourselves, and therefore are known in the physical terms (Shirazi, 1987, Vols. 1: 63). ${ }^{53}$ We need God's wealth in the light of his life. Or in terms of the philosophy of human existence, it is not necessary or compulsory, while the existence of God is a necessary or obligatory existence, without which the world does not exist ${ }^{54}$.

Not only in the process of creation, when a man was born on earth, he becomes an adult and he reasoned (Allah) also mastered it by applying the rules necessary for his servants to obey: So even human civilization should be based on what God has set, why not? Because he is in fact the king of the kingdoms of earth and of heaven, all his subjects must obey his rules. ${ }^{55}$

In addition, we know that God is all-knowing, so the rule He outlined is the best. Then through whom did God send His perfect rules and laws? With the reference to the Surah al-Jumu'ah verse 2, that the sending of the rule of God through the Messenger of the Prophets, which by its rules can bring mankind to perfection. Surah al-Jumu'ah mentions that the missions given by Allah, among others, are:

- Recite His verses, according to Tabațaba'i the verses referred to in this verse are verses that are written in writing, especially on the Prophet who was revealed to him the book or the sheets. ${ }^{56}$

- Perform the tazkiya process on his people. Tazkiya itself according to Tabațaba' $i$ has the meaning of a growth process that produces goodness and blessing. Prophets, Especially Prophet Muhammad was sent among the people who were very moral, even morally reprehensible. All the practices of evil, cruelty, and cruelty became the staple of the society so that the prophets were sent to grow morally amidst an ethically and morally degraded nation by accustoming them to be virtuous and virtuous, nothing

52 Țabațaba'i, Al-Mizan Fi Tafsir..., 236.

$$
\text { فله أن يتكم في نظام التكوين بين خلقه ما يشاء }
$$

53 Sadr al-Muta'alihin Shirazi, Tafsir Al-Qur'an Al-Karim (Qum: Bidar Publisher, 1987), 63.

54 Abu Ali Sina, Al-Isharat Wa Al-Tanbihat (Qum: Nashr al-Balaghah, 1996), 97.

55 Țabațaba'i, Al-Mizan Fi Tafsir..., 236.

$$
\text { وفي نظام التشريع في عباده بما أراد، كيف لا؟ وهو ملك له أن يحكم في أهل مملكتاه وعليهم أن يطيعوه }
$$

56 Ṭabațaba'i, Al-Mizan Fi Tafsir..., 264. 
more than to return. Refreshing their humanity and conscience so that they have a dignified and stable life. This is emphasized by Tabațaba'i: Tazkiya has the meaning of ta'fil as he quotes from the word zakat which has the meaning of enhancement which restricts goodness and fortune. Consequently, purification means a positive improvement effort by familiarizing them with the main Character and the good deeds, thus enhancing their humanity and the stability of their world and the hereafter. ${ }^{57}$

- Teach his people that what he has read from the book or sheet either explains the pronunciation-lafaz that is not clear or even explains the meaning of the verse. In addition to that, it also describes the wisdom or information that is important and found in the Qur'an. ${ }^{58}$

Surah of al-Jumu'ah verse 2 mentioned three things above as the missions of the Prophet to read the message of God, purify the people, and teach the people about the message of God revealed to them. These are the order of the mission of the Prophet. Then, the question is why the effort of the purification is more important than the teaching of the Qur'an and the related knowledge of the Qur'an. Tabataba'i answers the importance of the sanctification rather than the teaching is that because it has a meaning of moral growth and purification is the first step in the process of formation of the people towards the happiness of teaching the Qur'ann and Knowledge relating to the Qur'an: In this verse, Allah prefers sanctification (tazkiya) instead of teaching the Qur'ann and wisdom because this verse tells about the process or way the Prophet guides his people, and the process of purification (tazkiya) comes first rather than teaching science, Abraham. ${ }^{59}$

It can be concluded, in other words, the Prophet was more concerned with the elements of affinity (related to Values and attitudes) than cognitive (which is related to normative intellect/knowledge). Even this passage in al-Jumu'ah's Surah contains an insult to God to the people of Moses or more commonly called the Jews by being treated with a donkey that carries heavy books of knowledge. No matter how thick the book is, or the sheer brilliance of the writing style, the donkey cannot understand the book or book it carries. He just gets tired and tired. Why does God equate Jews

57 Țabațaba'i, Al-Mizan Fi Tafsir..., 264.

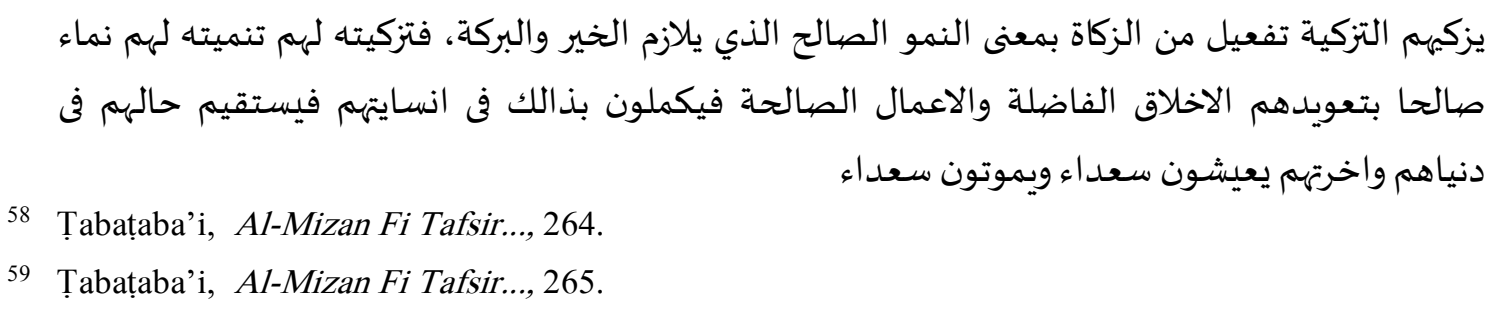

58 Țabaṭaba'i, Al-Mizan Fi Tafsir..., 264.

59 Țabațaba'i, Al-Mizan Fi Tafsir..., 265.

و قد قدم التزكية هاهنا على تعليم الكتاب و الحكمة بخلاف ما في دعوة ابراهيم ،لأن هذه الاية تصف تربيته (صلعم) لمؤمنين امتاه،و التزكية مقدمة في مقام التربية على تعليم العلوم الحقة و المعارف الحققية 
with the donkey above? According to the Bible, God equated the Jews with the donkey, because the Jews did not pay any attention to the important and important thing that Moses commanded and passed down the Torah to them, the practice of the value contained in it. in the Torah and its application to the Attitude (affinity), the Jews were only fixated on things that were cognitive and non-verbal, whereas the Prophet and his message or message were present rather than merely understood and memorized, and then left as they were. Tabațaba'i interprets through some of the fifth verse:

"The parables of those who were educated in the Torah then did not practice like a donkey carrying a bunch of books. The people who were taught the Torah were Jews who received the Book from God through their Prophet (Moses), then Moses taught them (the Jews) knowledge and rules, but as a result they abandoned it and did not practice it. God treated them with the donkeys that carried the books, but he knew the truth of the book, so that the result of carrying it was only exhausted after the heavy load.'

\section{E. From the Interpretation of Prophetic Mission toward the Construction of Spiritual Civilization}

In understanding the construction of spiritual civilization through the prophetic mission interpreted by Tabataba' $i$, it is necessary to establish the basic elements in spiritual civilization that Coomaraswamy mentioned earlier including king, society, and law. As for justice, it becomes a prerequisite as well as a vision for realizing an order of spiritual governance. These main concepts can be then linked as the basis of the construction of civilization as intended by God through the prophetic mission interpreted by Tabațaba'i.

The first and second elements of spiritual civilization (king and society) are found in the first verse. This is as interpreted by Tabațaba'i shows the absolute power of God as the king who governs nature as well as human dependence as a society that is his creation. This is marked by the characterization of the attributes of God in the form of: al-mālik, al-az̄iz, al-hakīm, as well as human imperative commands to always glorify which is the obligation of universal action as a determinant of perfection (human). The status of the king as mentioned by Coomaraswammy is an

60 Țabațaba'i, Al-Mizan Fi Tafsir..., 265.

$$
\begin{aligned}
& \text { مثل الذين حملوا التوراة ثم لم يحملوها كمثل الحمار يحمل اسفارا (المراد بتحميل التوراة تعليمها والمراد }
\end{aligned}
$$

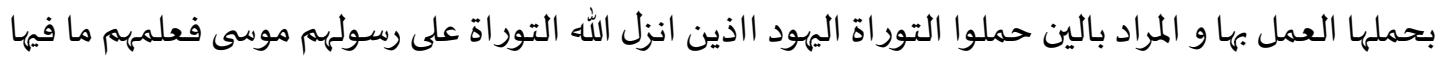

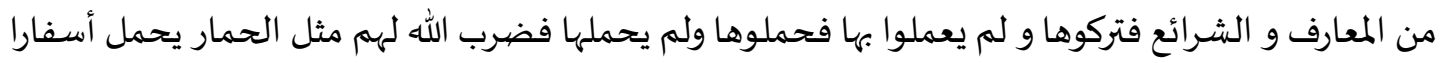

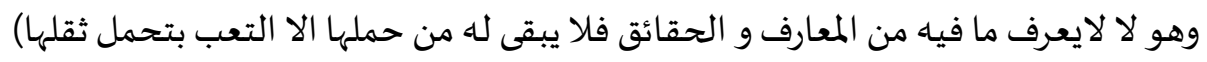


absolute principle of the existence or existence of the community so that the human relationship with God in a spiritual civilization is entirely dependent. By this logically it means that God becomes the determinant of all his creation and humans automatically as individuals become completely dependent on God. One of these principles is justified or in line with the philosophical arguments that Mulla Sadra proved that the relationship between humans and God is al-wujud al-ayn al-rabit (relational form). ${ }^{61}$

The consequence of the absolute dependence of humans, which in this case is a society on God as its king makes God the only authoritative one who decides on His creation. This, according to Tabațaba'I, happened in two ways including the process of its creation and the rules set or the law applied to its creation. In the explanation of his book, the following verse explains that the law or rules established by God can only be conveyed through the Prophet as a connecting line between God and humans. This is so that God's authority in determining the laws of civilization is not in line with what is conveyed by the prophet, because the Prophet is the conveyer of these laws of God.

The priority given by the Prophet based on Allah's commands in the verse shows to prioritize things that are effective, with the priority scale of the sequence of verses used to build the perfection of the people. ${ }^{62}$ Affection as the main thing or priority to achieve the perfection of the prophet's message will have consequences on the development of civilization that God intended in the interpretation of Tabațaba'i. The principle of the prophetic mission is in harmony with the principle of harmonization of Coomaraswamy's spiritual civilization in which the conditions for building a harmonious civilization depend on the actuality of the potentials of the human soul in the form of wisdom, serenity, and courage. These three qualities in the theory of human perfection are a middle attitude (lā ifrāt wa lā tafrīt) which results in the actuality of the potentials of the human soul. ${ }^{63}$ The basis for building these characteristics is generally complemented by the explanation of Tabataba'i about why tazkiya (purifying oneself) is preferred, because it is the main condition for achieving true happiness as explained in the theme of the height of spirituality. Thus the conditions for building a spiritual civilization in the form of law are in line with the priority of teaching prophetic missions. This means that when viewed from the perspective of the true prophetic mission directed to build a spiritual civilization where affective aspects are the basis of progress. This progress indirectly becomes the basis of whether or not the needs are filled, and, or human happiness, is the ultimate goal.

61 Shirazi, Tafsir Al-Qur'an Al-Karim, 63.

62 Țabațaba'i, Al-Mizan Fi Tafsir..., 265.

63 Hamim, "Pendidikan Akhlak: Komparasi...., 27-28. 
From the description so that, the interpretation of Tabațaba'i on al-Qur'an is related to the prophetic mission to construct a spiritual civilization in which God is the king and humans as the people. The establishment of the law in civilization depends on the servitude of humans as a society to God as a king as evidenced by the extent to which humans are able to actualize all the potentials of their souls by selfpurification (tazkiya).

\section{F. The Actualization of the Nusantara's Treasury Potential through the Construction of Spiritual Civilizations}

In language in the big Indonesian Dictionary (KBBI), the treasury is defined as wealth, collection or treasury. ${ }^{64}$ Whereas the archipelago in terms of language or naming for the entire territory of the Indonesian archipelago. The Indonesian archipelago in question covers Sumatra to Papua. The archipelago historically has strong historical roots in the aspects of spirituality this is in addition to being a treasure trove as well as national identity. She said, the local community at that time returned the cause of a phenomenon that was spiritual in nature:

"People often consider natural and supernatural spirits as the primary
causes of misfortunes as well as successes. As Indonesia is so diverse in
cultures and geography, specific beliefs about spirits vary greatly from
place to place. If, as in Bali and Java, world religions such as Hinduism
and Islam have been in place for centuries, local people have blended and
even elaborated their previous beliefs with these newer faiths in ways
that seem to fit. This is also true of many Indonesian Christians.
Unconverted animist societies persist in Indonesia, especially in the
eastern islands." 65

People often consider natural and supernatural spirits as the primary causes of misfortunes as well as successes. As Indonesia is so diverse in cultures and geography, specific beliefs about spirits vary greatly from place to place. If, as in Bali and Java, world religions such as Hinduism and Islam have been in place for centuries, local people have blended and even elaborated their previous beliefs with these newer faiths in ways that seem to fi t. This is also true of many Indonesian Christians. Unconverted animist societies persist in Indonesia, especially in the eastern islands. ${ }^{66}$

As for some of the activities and principles of the basic animistic beliefs of the Indonesian archipelago before the existence of the major religions, they consisted

\footnotetext{
64 Pusat Bahasa Departemen Pendidikan Nasional, Kamus Besar Bahasa Indonesia (KBBI) (Jakarta: Author, 2008), 1080.

65 Khorsidi and Mona, “Comparing Mulla Sadra and..., 30.

66 Khorsidi and Mona, "Comparing Mulla Sadra and..., 30.
} 
of several elements. "All contemporary world faiths include elements of animism (or paganism), based upon what people believed and did in ancient times before newer religions took hold. These elements include miracles, divine interventions, invisible spiritual realms, taboos, mythic beings, and the need to make offerings and pray to unseen powers. ${ }^{\prime 67}$ These elements then become the basis of the traditions of the nation which as a whole represent a strong spirituality culture. One of the models for the development of animism was successfully cultivated by Islamic tradition where Islamic Sufism became one of the strengths in developing the welfare of the nation. This is evidenced by its role which is not only engaged in ritual dhikr but also economic and especially resistance to the Dutch invaders. ${ }^{68}$

The construction of a spiritual civilization developed through the interpretation of the prophetic mission is in line and can take a role in maximizing the potential of the nation's spirituality treasures. This can happen to the potential of the archipelago, which in general has a strong attachment to God or something unseen. The construction of a spiritual civilization that has been built provides a fundamental solution in developing that potential where tazkiya (self-purification) is a condition for achieving the perfection of each human in a society. Perfection is directing man to the source of his existence. This is so that the abundance of knowledge is closer to its source. ${ }^{69}$

Also, the most fundamental reason is that the archipelago as a civilization will be formed according to or in accordance with what God wants as the sole king of the universe. It is the continuity between the king and society that can create an advanced civilization in which the inherent (deepest) aspects of humans are the basis of their size. This certainly does not deny aspects of materiality as a form of progress, because materiality is a consequence of deeper progress (spirituality). This has been proven in the history of medieval Islamic civilization where materiality in the form of the scientific world and godly consciousness go hand in hand, even all scientific activities become media to reveal knowledge about God, as revealed by Nasr: "The arts and sciences in Islam are based on the idea of unity, which is the heart of the Muslim revelation."70

Thus, the relationship between the community and God through this method gets very strong attachment. This is in addition to being in harmony with the main mission of the prophecy also in harmony with the function of the Prophet as a link between Allah and his servant. The strength of the relationship which is then very

67 Khorsidi and Mona, "Comparing Mulla Sadra and..., 30.

68 Nur and Abdurahman, "Sufism of Archipelago: History, Thought, and Movement", 68, 127.

69 Abu Ali Sina, Al-Shifa (Qom: Ayatollah Mar'ashi Najafi Library, 1984), 53.

70 Nasr, Knowledge and the Sacred, 21. 
potential to be possessed by the archipelago community, to be able to actualize the full potential of his treasures through self-purification efforts (tazkiya al-nafs). The actualization of the potential is in addition to the consequences on spiritual progress as well as on the material.

\section{G. Conclusion}

The interpretation of the prophetic mission in the Tafsīr of al-Mīzān has constructed a spiritual civilization in which God becomes a king and humans are its society. While the law established by this civilization based on nature or the potentials given by God to humans and their actuality is both a cause and a medium for achieving the progress of a spiritual civilization as well as a harmonious condition of that civilization. With this concept of civilization, the archipelago as a place with various spiritual treasury can maximize its potential for spiritual progress.

This study contributes to being complementary as well as new efforts in constructing a spiritual civilization based on the interpretation of the prophetic mission in the Qur'an. Besides, this study formulates the study of philosophy by means of Qur'anic interpretation so that it makes the Qur'anic discipline becomes a rational interpretation and can be communicated to the larger studies especially philosophy and science. 


\section{Bibliography}

Ahmad, Askar. "MISI PROPETIK PENDIDIKAN ISLAM: MEMBENTUK KARAKTER MENUJU TRANSFORMASI SOSIAL MEMBANGUN PERADABAN." HUNAFA: Jurnal Studia Islamika 8, no. 1 (June 15, 2011): 175. https://doi.org/10.24239/jsi.v8i1.93.175-188.

Baedhowi. "Memaknai Kembali Spiritualitas Islam Dalam Peradaban Kontemporer." Millah 3, no. 20 (2004): 221.

Borchert, Donald M. Encyclopedia of Philosophy. Edited by Donald M Borchert. New York: Thompson Gale Corporation, 2006.

Bunge, Mario M. Matter and Mind. Montreal: Springer, 2010.

Capra, Fritjof. The Web of Life. New York: An Anchor Book, 1996.

Cole-Turner, Ronald. Transhumanism and Transcendence. Washington DC: George Town University Press, 2011.

Coomaraswamy, Ananda K. The Essential Ananda K. Bloomington: World Wisdom, 2004.

—. What Is Civilization? United Kingdom: Lindisfarne Press, 1989.

Farooqui, Jamil. "Civilization In An Islamic Perspective." Journal of Islam in Asia (EISSN: 2289-8077) 8 (February 2, 2012): 409-26. https://doi.org/10.31436/jia.v8i0.244.

Forshee, Jill. Culture and Customs of Indonesia. London: Greenwood Press, 2006.

Goff, Peter $\mathrm{S}$, and Leaman Oliver. Islamic Philosophy A-Z. Edinburg: Edinburg University Press, 2007.

Hamim, Nur. "Pendidikan Akhlak: Komparasi Konsep Pendidikan Ibnu Miskawaih Dan Al-Ghazali." Ulumuna 18, no. 1 (November 8, 2017): 21-40. https://doi.org/10.20414/ujis.v18i1.151.

Hashtroodi, Fatemeh Tayefeh Aghakhan. Concept of Chivalry (Futuwwah) According to Abd al-Razzaq Kashani: Analysis on His Tuhfah al-Ikhwan fî Khasāis alFityan. Kuala Lumpur, Malaysia, issued 2015.

Huff, Toby E. The Rise of Early Modern Science. New York: Cambridge University Press, 2003.

Irham, Iqbal, and Muhammad. Menghidupkan Spiritualitas Islam: Kajian Terhadap Konsep Hudur Ibn Al-Arabi. Jakarta: Semesta, 2016. 
Khorsidi, Faridi, and Mona. "Comparing Mulla Sadra and Ibn Turka Viewpoints Regarding Angelic Inspiration.” J. Basic. Appl. Sci. Res 3, no. 2 (2013): 582.

Labib, Muhsin. Pemikiran Filsafat Ayatullah M.T Misbah Yazdi. Jakarta: Sadra Press, 2011.

Lufaefi, Lufaefi. "REKONSTRUKSI JARGON FORMALISASI SYARIAT: UPAYA MENJAGA PERSATUAN DALAM BINGKAI KEBERAGAMAN." $A l-A$ 'raf: Jurnal Pemikiran Islam Dan Filsafat 14, no. 1 (June 27, 2017): 73. https://doi.org/10.22515/ajpif.v14i1.805.

Miftahusyaian, Moh. "SPIRITUALISASI KEILMUAN: Mengkonstruksi Peradaban Intelektual Muslim Abad Ke-21.” El-HARAKAH (TERAKREDITASI) 1, no. $\begin{array}{lllllll}\text { arakah. } \quad \text { Vol. } 12 . & \text { No. } 1 & \text { (April 30, }\end{array}$ https://doi.org/10.18860/el.v0i0.439.

Nasr, Seyyed Hossein. History of Islamic Philosophy. London: Routledge, 1996.

- Knowledge and the Sacred. New York: State University of New York Press, 1989.

Nur Aziz, Afandi. "Spiritual Path of Grave Digger." Teosofia: Indonesian Journal of Islamic Mysticism 7, no. 1 (2018).

Nur, Syaifan, and Dudung Abdurahman. "Sufism of Archipelago: History, Thought, and Movement." ESENSIA: Jurnal Ilmu-Ilmu Ushuluddin 18, no. 2 (May 20, 2018): 123. https://doi.org/10.14421/esensia.v18i2.1476.

Pusat Bahasa Departemen Pendidikan Nasional. Kamus Besar Bahasa Indonesia (KBBI). Jakarta: Author, 2008.

Shirāzi, Sadr al-Muta'alihīn. Mazāhir Al-Ilāhiyyah Fì Asrar Al-Ulūm Al-Kamāliyyah. Tehran: Sadra Foundation of Islamic Philosophy, 1999.

. Tafsir Al-Qur'ān Al-Karìm. Qum: Bidar Publisher, 1987.

Sina, Abu Ali. Al-Isharāt Wa Al-Tanbihāt. Qum: Nashr al-Balaghah, 1996.

—. Al-Shifã. Qom: Ayatollah Mar'ashi Najafi Library, 1984.

Syihabuddin Umar Suhrawardi. Al-Awarif Al-Ma'arif. Kairo: Dar Al-Ma'arif, 1970.

Tabātabā'i, Muhammad Husein. Al-Mīzān Fī Tafsìr Al-Qur'ān. Vol. Vols. 19. Qum: Mansturat Jamīah Mudarrisin fỉ Hauzah Ilmiyah, 1997.

Tibi, Bassam. Islamism and Islam. London: Yale University Press, 2012.

Vasiltov, K. "Afdal Al-Din Kashani and His Treaties: The Book of Everlasting." International Journal for Oriental Manuscript Research 10, no. 4 (2004): 10. 
Wahid, Abd. “Al-Qur'ān Sumber Peradaban”. Ushuluddin” 18, no. 2 (2012): 111,122. https://doi.org/http://dx.doi.org/10.24014/jush.v18i2.703. 